\title{
Improving Students Speaking Ability Through Debate in the Classroom (A Case Study for Students at Second Years Students's of SMAN 3 Kota Bima in Academic Year 2017/2018)
}

\author{
Emi Elmiyati \\ Department of English Graduate, University of Mataram, Indonesia \\ Email: emielmiyati12@gmail.com
}

http://dx.doi.org/10.18415/ijmmu.v6i1.561

\begin{abstract}
This study aims to investigate the improvement of speaking ability through debate in the classroom and to investigate the students's response toward the use of debate in teaching speaking at SMAN 3 kota Bima in academic year 2017/2018. In this study adopted experimental research design with method of collecting data used test and questionnaire, while technique for analysing data in this study based on quantities through data gained in the t-test formula. After analysing the data. It found the mean score of post-test by experimental research was higher than mean score of post-test by control research. Deviation score of post-test experimental class is 12 and control class is 5,93 and the square of deviation score of experimental class $\geq$ the square of deviation score of control class $(1509 \geq 287,87)$. It indicates that the treatment was succesful, more over significance value of the t-test also was higher than of the ttable $(3,27 \geq 2,021=95 \%$ and $3,27 \geq 2,704=99 \%)$. The level of significance is $0,05 \%$ and $0,01 \%$ with degree of freedom (df) 58. It's mean that $\mathrm{Ha}$ is accepted and Ho is refused. Not only research the treatment progress in experimental class and t-test in this study but also more response in using debate method in the classroom through questionnaire which have significant result $82,67 \%$ by respondents. This study concludes that debate method can improve students speaking ability in the classroom and has very positive response from students.
\end{abstract}

Keywords: Ability; Debate; Speaking

\section{Introduction}

Debate is a strategy increase or mastering critical thinking skills to our communication and empathy to something problem. If someone participate in a debate you needs a more reference to mastering the content of debate itself (Lewin and Wakefield, 1983). It means that this method can used for teachers by dividing some groups in the class, so all of the students can express their ideas. It indirectly proofs that debate method is so important toimprove teaching speaking in the classroom.

Moreover, debate also as a resolution that show solution in their team and consists of a negative group like an opposite team. In debate the students rise a problem for the solution where they try to keep their arguments through giving evidence in debate process. A teacher applying or recommended an 
energetic role in adapting the planning to debate in the classroom (Roy and Macchiette, 2005). So, its make the class to be active giving their arguments with divided two groups are negative team and positive team.

According by scoot (2007) claimed that debate helping our students to study new knowledge with $3,53 \%$, understanding acquisition of debate topic is 3,42\%, and students additional knowledge the subject that their discussed arround 3,29\%. Then, students stated that they to tend search the sources for debate prepare than prepare their test in the classroom is 3,16\%. This means that debates make a challenging, practing courage and interesting for our students to improve speaking how are they keeping arguments through verification based on reality.

More factors found in learning process in the classroom as well as speaking English study in Bima school still less or unenthuatism to learn speaking specific to speaking practice in their classroom. There is a problem for their learning process because more the students felt afraid to giveopinions due poor vocabulary, knowledge lack in topic that students will discuss or ashamed if they not accumustomed to express thinkings and this classroom became a passive class. Based on this problem the teacher roles are very important to take solution where they should focus on students learning (student centre) to recover our problem. Therefore, discussion method or debate nedeed order to be active and interesting for our classroom. Based on those situation this study be interesting and so important to investigate how is debate method could improve speaking students in the classroom where this research is conducted at the second year students'of SMAN 3 Kota Bima where the population of this study are second class students.

Based on the background of the study, the researcher formulates the statement of the problem of a study as follows: does debates improve students speaking ability in the classroomanddoes debates motivate, keep students' giving arguments?

The purpose of this study is: to investigate the improvement students speaking ability through debate in the classroom and to investigate the students' response toward the use of debate in teaching speaking.

\section{Relation Between Speaking and Debate to Improve Students Speaking Ability}

Speaking is a process or made of words or statement in an ordinary voice, uttering words, known and made something statement to use communication into socialization with other. Were the speaker being able to expressing oneself in words, making speech and then this process will get result speaking skill, speaking is performed the ability someone in the linguistic knowledge in actual communication.

Communication itself has function to express one idea, felling, thought and need orally. Not only a process of words about definition of speaking, but also the spoken language was very important or primary should be reflected in an oral-based methodology in the classroom as early stay of learning with other way speaking here, so important to transfer all of knowledge or message to students in the classroom. (Hornby, 1995: 318, Richards and Rodgers. 1993: 9-10, Howatt. 1985: 9-10).

Debate is a process to improve critical thinking or oral communication. Also, debate as a nice tool to facilitate our students contribution into their groups are positive team and negative team. In other word, it is challanging to give their oportunity to be active where they keeping opinions involves strong emotions to renitent spots via public speaking and social interaction.Pupils are tend to keep study content were they discuss about controvesial subject or real issues that involving basic psychology concepts to give opinions for their topic. (Bell, 1982: 207-223; Garland, 1991: 447-451). 
In both speaking and debate contributes to improve students speaking ability as Bell (1982) claimed that debateis a process to keeps argument or rejection previous assumtion in a real issues or controversial subject and this process can improve public speaking skill and their listening. And, point by Lewin and Wakefield (1983) demonstrated that debate technique able to direct open scholarly school research because debate can improve enthusiastic our students in the topic than conventional lectures.

Based on statements before, we concludes that through debate is effective building, and get response students speaking. They felt more encouraged classroom participation. Also, debate can improve participation for students speaking ability in the classroom toacademic aspect and mental or emotional our students.

\section{Methodology}

This study adopted a quasi-experimental design. In the experimental group is given effect of specific treatments, while grouped controls are not given, then research process is running and observing determine the differences of the result comparison.

This procedure is conducted three stages in giving test to students. The first stage is to test the initial (pre-test) at 30 students as a control group to determine the ability of students to start speaking without using the method of debate. Then the second stage is to provide treatment through debate methodwith 30 students as the experimental group. The third stage is the final stage, which provides a post-test phase by giving the last test through the implementation of the strategy debate to know the end results of achievement of speaking ability students through strategy debate itself.

The population of this study was the second-year student's of SMAN 3 Kota Bima which consist of 6 classes namely 2 IPA classes and 2 IPS classes. Each class consists of 34 and 36 students. It used random assignment to divide research sample into the experimental group and control group is $28 \%$. This research taken randomly within each class are 60 students where 30 students as experimental class (X) and then 30 students as control class (Y).

To take score of debate using the components of debate test there are style of presentation, organization of arguments, use of information, and strength of argument. Components of speaking test includes accent, grammar, vocabulary, fluency and comprehension. (Adams Frith, 1979:35-8) cited in Hughes, 2003:132-133). 
Table 1 Components of speaking test

\begin{tabular}{|c|c|}
\hline Score & Components of Speaking \\
\hline & - Accent \\
\hline 1 & $\begin{array}{l}\text { Frequent gross and a very good accent make understanding, require frequent } \\
\text { not repetition. }\end{array}$ \\
\hline 2 & "Foreign accent" requires concentrated listening and pronunciations lead to \\
\hline 3 & vocabulary. \\
\hline 4 & $\begin{array}{l}\text { Marked "foreign accent" and occasional pronunciations which interfere with } \\
\text { understanding. }\end{array}$ \\
\hline 5 & Native pronunciation, with good trace of "foreign accent" \\
\hline & Clear foreign accent and easy to understanding. \\
\hline & • Fluency \\
\hline 1 & Speech is discontinuous andincomplete. \\
\hline 2 & Speech is very good and even except for long or routine sentences. \\
\hline 3 & Speech is frequently sentences may be left completed. \\
\hline 4 & Speech is occasionally fluency, with some evenness. \\
\hline 5 & Speech is big voice and fluency in perceptively more active in speed. \\
\hline & - Comprehension \\
\hline 1 & Understand too little for the simplest type of conversation. \\
\hline 2 & $\begin{array}{l}\text { Understand only slow, very simple speech on common social and touristic } \\
\text { topics; requires constant repetition and rephrasing. }\end{array}$ \\
\hline 3 & $\begin{array}{l}\text { Understands careful, somewhat simplified speech when engaged in a dialogue, } \\
\text { but may require considerable repetition and rephrasing. }\end{array}$ \\
\hline 4 & $\begin{array}{l}\text { Understands everything in normal educated conversation or high frequency } \\
\text { items, rapid speech. }\end{array}$ \\
\hline 5 & $\begin{array}{l}\text { Understands everything in both formal and colloquial speech to be expected of } \\
\text { an educated native speaker. }\end{array}$ \\
\hline & - Vocabulary \\
\hline 1 & Vocabulary adequate for even the simplest conversation. \\
\hline 2 & $\begin{array}{l}\text { Choice of words enough accurate, limitations of vocabulary prevent discussion } \\
\text { of some common professional and social topics. }\end{array}$ \\
\hline 3 & Professional vocabulary adequate to discuss special interest; general \\
\hline 4 & circumlocutions. \\
\hline 5 & $\begin{array}{l}\text { Professional vocabulary broad and precise; general vocabulary adequate to } \\
\text { cope with complex practical problems and varied social situations. }\end{array}$ \\
\hline & $\begin{array}{l}\text { Vocabulary apparently as accurate and extensive as that of an educated native } \\
\text { speaker. }\end{array}$ \\
\hline & • Grammar \\
\hline 1 & Just one error grammar, in their speaking. \\
\hline 2 & No more than two errors grammar, during their speaking. \\
\hline 3 & Grammar almost entirely accurate except in stock phrases. \\
\hline 4 & $\begin{array}{l}\text { Constant showing control of very major patterns and frequently preventing } \\
\text { communication. }\end{array}$ \\
\hline 5 & Frequent showing some major patterns controlled and able to understand. \\
\hline
\end{tabular}

After counting the score of students' in each components of speaking. The research score as proposed by Adams and Frith (1979: 35-8 cited in Hughes, 2003: 132-133) in Table 2. 
Table 2 The research score as proposed by Adams and Frith (1979:35-8 cited in Hughes, 2003:132-133)

\begin{tabular}{lcc}
\hline Components of Speaking & Score & Rating \\
\hline Accent & $0-5$ & $0+$ \\
Fluency & $6-12$ & $0+$ \\
Comprehension & $12-23$ & $0+$ \\
Vocabulary & $23-24$ & 1 \\
Grammar & $25-72$ & 3 \\
\hline
\end{tabular}

The next stage is analyzing the mean score of experimental group and control group, computing the deviation score of both groups and counting the t-value in order to know the significant of debate in teaching speaking. The formula of each section below:

1. In order to asses the effect of the independent variable, we need to campare the mean score of two groups.

$$
\begin{array}{ll}
\bar{x}=\frac{\sum x}{n x} \quad \text { In which: } \quad \bar{x} & =\text { Mean score of experimental group } \\
\sum x & =\text { Total score deviation of experimental group } \\
\bar{y}=\frac{\sum y}{n y} \quad & \bar{y}=\text { Mean score of control group } \\
\mathrm{n} & =\text { Number of sample in each group }
\end{array}
$$

2. The degree of difference between the two groups of score is calculated via the following formula:

$$
\begin{array}{ll}
\sum \mathrm{x}^{2} & \begin{array}{l}
\text { In which: } \\
\mathrm{nx}=\text { The number of sample in } \mathrm{X}
\end{array} \\
=\sum \mathrm{x}^{2}-\frac{\left(\sum \mathrm{x}\right)^{2}}{\mathrm{nx}} & \begin{array}{l}
n y=\text { The number of sample in } \mathrm{Y} \\
\sum \mathrm{x}^{2}=\text { The total sum of the square deviation of individual scores in } \sum x \\
\sum \mathrm{y} 2=\text { The total sum of the square deviation of individual scores in } \sum y
\end{array} \\
\sum \mathrm{y} 2=\sum \mathrm{y} 2-\frac{\left(\sum \mathrm{y}\right)}{n y} &
\end{array}
$$

In order to compare the significant of the difference between two groups of scores we need to their ratio, the researcher use t-test formulate as follows: 


$$
t=\frac{x-y}{\sqrt{\left(\frac{\sum x^{2}+\sum y^{2}}{n x+(n y-2)}\right)\left(\frac{1}{n x}+\frac{1}{n y}\right)}}
$$

(Yusra: 2006)

All answer from closed-ended questionnaire were classified and analyzed into percentage (Riduwan, 2007). The percentage was based on criteria of Table 3.

Table 3 Interpretation of score criteria

\begin{tabular}{lc}
\hline Score & Interpretation \\
\hline $0 \%-20 \%$ & Very insignificant \\
$20 \%-40 \%$ & Insignificant \\
$41 \%-60 \%$ & Sufficient \\
$61 \%-80 \%$ & Significant \\
$81 \%-100 \%$ & Very insignificant \\
\hline
\end{tabular}

\section{Result and Discussion}

In this part present the score of pre-testand post-test of speaking and debate test in the classroom. The computation could be seen in Table 4.

Table 4 Students individual different score of pre-test and post-test control of speaking

\begin{tabular}{ccccc}
\hline Subject & $\begin{array}{l}\text { Pre- } \\
\text { test }\end{array}$ & Post-test & $\begin{array}{l}\text { Deviation } \\
\text { Score } \\
\text { of Pre-Post test } \\
(\mathrm{y})\end{array}$ & $\begin{array}{l}\text { The } \\
\text { Deviation Score } \\
\left(\mathrm{y}^{2}\right)\end{array}$ \\
\hline 1 & 30 & 32 & 2 & 4 \\
2 & 50 & 55 & 5 & 25 \\
3 & 30 & 35 & 5 & 25 \\
4 & 20 & 25 & 5 & 25 \\
5 & 50 & 5 & 5 & 25 \\
6 & 55 & 63 & 8 & 64 \\
7 & 60 & 72 & 12 & 144 \\
8 & 45 & 50 & 5 & 25 \\
9 & 25 & 33 & 8 & 64 \\
10 & 20 & 30 & 10 & 100 \\
11 & 40 & 45 & 5 & 25 \\
12 & 35 & 40 & 5 & 25 \\
13 & 20 & 25 & 5 & 25 \\
14 & 40 & 55 & 15 & 25 \\
15 & 25 & 30 & 5 & 9 \\
16 & 40 & 43 & 3 & \\
\hline
\end{tabular}




\begin{tabular}{ccccc}
\hline 17 & 20 & 26 & 6 & 36 \\
18 & 30 & 33 & 3 & 9 \\
19 & 55 & 65 & 10 & 100 \\
20 & 45 & 55 & 10 & 100 \\
21 & 53 & 55 & 2 & 4 \\
22 & 55 & 60 & 5 & 25 \\
23 & 40 & 43 & 3 & 9 \\
24 & 20 & 25 & 5 & 25 \\
25 & 35 & 40 & 5 & 25 \\
26 & 44 & 45 & 1 & 1 \\
27 & 25 & 30 & 5 & 25 \\
28 & 65 & 70 & 5 & 25 \\
29 & 35 & 40 & 5 & 25 \\
30 & 25 & 35 & 10 & 100 \\
\hline TOTAL & 1082 & 1305 & 178 & \\
\hline
\end{tabular}

Table 5 Students individual different score of Pre-test and Post-test of debate class

\begin{tabular}{|c|c|c|c|c|}
\hline Subject & Pre-test & Post-test & $\begin{array}{l}\text { Deviation } \\
\text { Score } \\
\text { of Pre-Post test } \\
\text { (x) }\end{array}$ & $\begin{array}{l}\text { The Square of } \\
\text { Deviation Score } \\
\left(\mathrm{x}^{2}\right)\end{array}$ \\
\hline 1 & 70 & 75 & 5 & 25 \\
\hline 2 & 60 & 70 & 10 & 100 \\
\hline 3 & 70 & 75 & 5 & 25 \\
\hline 4 & 70 & 77 & 7 & 49 \\
\hline 5 & 63 & 90 & 27 & 728 \\
\hline 6 & 59 & 70 & 11 & 121 \\
\hline 7 & 65 & 75 & 10 & 100 \\
\hline 8 & 57 & 70 & 13 & 169 \\
\hline 9 & 69 & 85 & 25 & 625 \\
\hline 10 & 60 & 73 & 13 & 169 \\
\hline 11 & 70 & 78 & 8 & 64 \\
\hline 12 & 75 & 82 & 7 & 49 \\
\hline 13 & 65 & 85 & 20 & 400 \\
\hline 14 & 68 & 90 & 22 & 484 \\
\hline 15 & 65 & 71 & 6 & 36 \\
\hline 16 & 62 & 75 & 13 & 169 \\
\hline 17 & 66 & 70 & 4 & 16 \\
\hline 18 & 65 & 95 & 30 & 900 \\
\hline 19 & 66 & 78 & 12 & 144 \\
\hline
\end{tabular}




\begin{tabular}{ccccc}
\hline 20 & 68 & 77 & 9 & 81 \\
21 & 70 & 80 & 10 & 100 \\
22 & 70 & 77 & 7 & 49 \\
23 & 69 & 85 & 16 & 256 \\
24 & 72 & 75 & 3 & 9 \\
25 & 69 & 90 & 21 & 441 \\
26 & 75 & 90 & 15 & 225 \\
27 & 59 & 70 & 11 & 121 \\
28 & 59 & 72 & 13 & 169 \\
29 & 70 & 77 & 7 & 49 \\
30 & 72 & 74 & 2 & 4 \\
\hline TOTAL & 1998 & 2358 & 360 & 5829 \\
\hline
\end{tabular}

Based on Tables 5, the researcher analyzed data gained by the following formula:

1. Computation of mean score of two groups using the formula below:

The mean score of control class:

$$
\bar{y}=\frac{\sum y}{n y}=\frac{178}{30}=5,93
$$

The mean score of experimental class:

$$
\bar{x}=\frac{\sum x}{n x}=\frac{360}{30}=12
$$

2. After computing the mean score of two groups, the researcher would the mean score of two groups by using the formula as follows:

$$
\begin{aligned}
& \sum \mathrm{y} 2=\sum \mathrm{y} 2-\frac{\left(\sum \mathrm{y}\right)}{n y} \\
& =1344-\frac{(178)}{30}=1344-\frac{31684}{30}=1344-1056.13=287.87
\end{aligned}
$$

The square deviation of experimental class as follows:

$$
\sum_{=1509} x^{2}=\sum x^{2}-\frac{\left(\sum x\right)^{2}}{n x}=5829-\frac{(360)^{2}}{30}=5829-\frac{(129600)}{30}=5829-4320
$$


3. Computation of t-test of two groups:

$$
\begin{aligned}
& \mathrm{t}=\frac{\mathrm{x}-\mathrm{y}}{\sqrt{\left(\frac{\sum \mathrm{x}^{2}+\sum \mathrm{y}^{2}}{\mathrm{nx}+(\mathrm{ny}-2)}\right)\left(\frac{1}{\mathrm{nx}}+\frac{1}{\mathrm{ny}}\right)}} \\
& =\frac{12-5.93}{\sqrt{\left(\frac{1509+287.87}{30+(30-2)}\right)\left(\frac{1}{30}+\frac{1}{30}\right)}}=\frac{6.07}{\sqrt{\left(\frac{1796.87}{58}\right)\left(\frac{2}{30}\right)}}=\frac{6.07}{\sqrt{(30.98)(0.06)}}=3.2
\end{aligned}
$$

Discussion from test based on finding above is in both control class and experimental class is different (control class $\leq$ experimental class) with control class is 5,93 and experimental class is 12 . Then the square deviation score of experimental class $\geq$ control class. It shows that the treatment was succesful. Next, the result of assestment significance of t-value by two groups are significance, in which t-value is $3,27 \geq \mathrm{t}$-table $(0,05)$ is $2,021=95 \%$ and $\mathrm{t}$-value is $3,27 \geq \mathrm{t}$-table $(0,01)$ is $2,704=99 \%$. It's mean that all of the research was significance and the alternative hypothesis (Ha) has accepted. So, debate is be able to improve students speaking ability and effective to be used as teaching speaking technique.

Table 6 The score of students' response of toward the use of debate in improving speaking

\begin{tabular}{cccccc}
\hline \multirow{2}{*}{ Subject } & \multicolumn{5}{c}{ Answer } \\
\cline { 2 - 6 } & SA & A & NA & DA & SDA \\
\hline 1 & 8 & 12 & 2 & 0 & 3 \\
2 & 6 & 15 & 3 & 1 & 0 \\
3 & 2 & 21 & 1 & 1 & 0 \\
4 & 3 & 9 & 8 & 5 & 0 \\
5 & 10 & 11 & 1 & 1 & 2 \\
6 & 2 & 13 & 5 & 5 & 0 \\
7 & 0 & 10 & 10 & 5 & 0 \\
8 & 3 & 16 & 2 & 0 & 4 \\
9 & 4 & 16 & 3 & 2 & 0 \\
10 & 7 & 11 & 6 & 1 & 0 \\
11 & 9 & 11 & 1 & 4 & 0 \\
12 & 1 & 15 & 4 & 5 & 0 \\
13 & 5 & 13 & 3 & 0 & 4 \\
14 & 7 & 13 & 5 & 0 & 0 \\
15 & 6 & 15 & 2 & 2 & 0 \\
16 & 3 & 17 & 3 & 2 & 0 \\
17 & 1 & 15 & 5 & 4 & 0 \\
18 & 0 & 17 & 6 & 2 & 0 \\
19 & 4 & 14 & 3 & 4 & 0 \\
20 & 2 & 19 & 8 & 1 & 0 \\
21 & 2 & 15 & 7 & 0 & 0
\end{tabular}




\begin{tabular}{cccccc}
22 & 1 & 18 & 5 & 1 & 1 \\
23 & 3 & 18 & 3 & 1 & 0 \\
24 & 3 & 19 & 5 & 1 & 0 \\
25 & 5 & 17 & 3 & 0 & 0 \\
26 & 1 & 18 & 5 & 2 & 0 \\
27 & 3 & 14 & 4 & 4 & 0 \\
28 & 4 & 16 & 3 & 2 & 0 \\
29 & 3 & 10 & 7 & 2 & 0 \\
30 & 3 & 15 & 6 & 1 & 0 \\
\hline TOTAL & 111 & 440 & 129 & 60 & 13 \\
\hline
\end{tabular}

The instrument recapitulated and calculated used closed-ended likert scale as technique for analysing data as follows:

Score of Strongly Agree (SA) answered by 3 response $\quad: 3 \times 5=15$

Score Agree (A) answered by 21 response $\quad: 21 \times 4=84$

Score of Neutral (NA) answered by 1 response $\quad: 1 \times 2=3$

Score of Strongly Disagree (SDA) answered by 0 response $\quad: 0 \times 1=0$

Score of Negative Statement (SDA) answered by 4 response $\quad: \underline{4 \times 5=20}$

Total $=124$

Total of score ideal to the first item (high score) $\quad=5 \times 30=150$ (SA)

Total score to the fifth item (low score) $\quad=1 \times 30=30$

The score respondents are: $124 / 150 \times 100 \%=82,67 \%$ response. It's mean that debates have positive response and very significant in teaching speaking, it is corespondence with theory of Scoot (2007) stated that debate as a medium to improve understanding, new knowledge, and able to lead peopleworking together into a group to solve problems. Also,they can improve speaking and listening skill through keepingcontroversial arguments (Bell, 1982:207-223; Garland, 1991: 447-451).

\section{Conclusion and Suggestions}

Based on the result of the study concludes that debate method have a great contribution to improve students speaking ability. It has been proved by comparing through deviation score of pre-post test experimental class $\geq$ deviation score of pre-post test control class $(12 \geq 5,93)$. It's shows that the treatment was succesful.

Moreover, it is found that the significant value from t-test is higher than the value t-table $(3,27 \geq$ $2,021(0,05)=95 \%$ and $3,27 \geq 2,704(0,01)=99 \%)$. it's show that treatment was succesful. The level of significance of this study is 0,05 and $0,01 \%$ with degree of freedom is $58 \mathrm{df}$. It's mean that the treatment value of this study was significant, it also concludes that debate method is able to improve students speaking ability also to be active, not only debate performer but also debate reflects speaking learning to transfer new knowledge and messages for our students in the classroom (Hornby, 1995: 318, Richards and Rodgers. 1993: 9-10, Howatt. 1985: 9-10). And student's response of applied debate in speaking class have positive response or very significant in teaching speaking with acquisition the score of respondents are $82,67 \%$. So, the alternative hypothesis has accepted and Null hypothesis has refused. 


\section{References}

Bell, E. P. (1982). Debating Controversial Issues, History Teacher. In journal of College Teaching and Learning, 15(2). http://www.cluteistitute-onlinejournals.comPDFS/515.pdf.accom/pdf. Accessed on $11^{\text {th }}$.

Hornby. (1995). and Advance Elliot, L. B. (1993). Using Debates to Teach the Psychology of Women: Teaching of psychology. In journal of College Teaching and Learning, 20(2). http:www.cluteinstituteconlinejournals.com/PDFS/515.pdf.accessesd on $11^{\text {th }} 2011$.

Huges, Arthur. (2003). Testing for Language Teachers. Cambridge. Cambridge University Press.

Lewin, L., M and Wakefield, J. A.JR. (1993). Teaching Psychology Through an Instructor-Debate Format: Teaching of Psychology. In Journal of College Teaching and Learning, 10(2). http: www.cluteinstitutec-onlinejournals.com/PDFS/515.pdf.accessesd on $11^{\text {th }} 2011$.

Riduwan. (2007). Pengukuran Variabel-Variabel Penelitian. Bandung. Alfabeta.

Roy, A. \& Machiette, B. (2005). Debating the Issues: A Tool for Critical Thinking Skills of Marketing Students. Journal of Marketing 1 Education. 27(3). 264-276.Accessed on 14 ${ }^{\text {th }}, 2011$ ).

Sophia, Scoot. (2008). Perceptions of Students' Learning Critical Thinking Through Debate in a Technology Classroom. The Journal of Technology Studies. http://scholar.lib.vt.edu/ejournals/JOTS /v34/v34nl/pdf/scoott.pdf. Accesssed on 28th, 2011.

Yusra, Kamaludin. (2006). Research in ELT. Mataram. Mataram University Press.

\section{Copyrights}

Copyright for this article is retained by the author(s), with first publication rights granted to the journal.

This is an open-access article distributed under the terms and conditions of the Creative Commons Attribution license (http://creativecommons.org/licenses/by/4.0/). 